\title{
An Experimental Study of Teaching Vocabulary by Using Hyponymy Games at Seventh Grader F of MTs Syech Ibrahim Payakumbuh
}

\author{
Fadilla Taslim \\ Department of English, STKIP Abdi Pendidikan Payakumbuh, Indonesia \\ Email: Fadila_dila@yahoo.com \\ DOI: http://dx.doi.org/10.15548/jt.v21i3.103
}

\begin{abstract}
Language is an effective tool to get communication, interaction, and information about other people, society and other groups. Whenever people think about language, they usually think of mastering vocabulary. Mastering vocabulary means that they know all the words in the language which we use. In this research, the writer would like to carry out the research under title "An Experimental Study of Teaching Vocabulary by Using Hyponymy Games on the Seventh Grader of MTs Syech Ibrahim Payakumbuh. It was quasi experimental method. The population was all of the seventh grader at Seventh Grader of MTs Syech Ibrahim Payakumbuh. But, the writer just took one class as the sample. The objects of the study was the seventh grade of $7_{\mathrm{c}}$ class. From the result of statistic calculation, it is obtained the value of $t_{0}$ is 8,9 and $t \mathrm{t}$ is 2,64 . So to $>$ tt. The comparison between t-score with t-table $(2,64<8,9)$. It means that hypothesis of the research is accepted, or there is significant difference between the results of teaching vocabulary through hyponymy games for the Seventh Grader of MTs Syech Ibrahim Payakumbuh.
\end{abstract}

Keywords: Vocabulary, hyponymy games, quasi experiment.

\section{INTRODUCTION}

Language which is a means of human communication consists of words that have structure which is used together by a particular community or country in conventional way. As the system of communication, it is used to express thought by one person to another person. Gonzalez $(2004,2)$ said that, "Language are more than skills; they are the medium through which communities of people engage with, make sense of and shape the world." Accordingly, language is an effective tool to get communication, interaction, and information about other people, society and other groups.

Language helps them to understand ourselves and the world around them. Zaenuri $(2001,9)$ says that "Language helps you to understand yourself and the world around you. " Without language, people will be easy getting confused with another. Therefore, language is the most important for human live. Whenever we think about language, we usually think of mastering vocabulary. It means whenever we use language automatically we use the words of the language. So, it is crucial for us to have large of vocabulary. By having large vocabulary, we can precisely open our ideas in communication. It also helps us travel in the past, present, and future.

It is important to master all of vocabularies in language. Mastering vocabulary means that we know all the words in the language which we use. Although, in fact, there is nobody can master all of words in language either native or foreign language. Yet someone who creates dictionaries can not do it either.

Schmitt and Mc. Carthey $(1997,40)$ say that "Vocabulary is one of important skills in language." We use words and arrange them together to make sentence, conversations, and discourse all things. We cannot express our ideas if we do not master it. Then, Harmer $(2001,153)$ said "An ability to manipulate grammatical structure does not have any potential for expressing meaning unless words are used." 
Furthermore, Rivers in Nunan (1991, 117) has also argued that "The acquisition of an adequate vocabulary is essential for successful second language use because, without an extensive vocabulary, we will be unable to use the structures and the functions we may have learned for comprehensible communication." So, no matter how well we master grammar, no matter how successfully the sounds of a foreign language is mastered, without words to express, communication can't happen in meaningful ways.

There are many reasons for people to study language. Harmer (2001, 1-2) concluded "there are six reasons, such as target language community, ESP, school curriculum, culture, advancement, miscellaneous." For Indonesian students, they have to study English language besides Indonesian language as the foreign language. Thus, English is the main subject in curriculum which should be learnt from secondary level up to university. Although in general, English is still considered as a difficult subject for the students because it is completely different from Indonesian language in the system of structure, pronunciation and vocabulary. The Indonesian government has also shown its attention in the 2004 English curriculum.

"Mata pelajaran bahasa Inggris
bertujuan mengembangkan
kemampuan berkomunikasi dalam
bahasa tersebut, dalam bentuk lisan
dan tulis. Kemampuan
berkomunikasi meliputi menyimak
(listening), berbicara (speaking),
membaca (reading), dan menulis
(writing).(Depdiknas, 2003: 14)

According to the statement above, the aims of teaching English in Indonesia are to develop the ability of using English in many skills for example listening, speaking, reading and writing. Therefore, the English teachers are supposed to be able to organize teaching learning activities. They may develop their students' ability by using English as a target language in the classroom. They may give practice in pattern which contains the vocabulary items for everyday situations such as listening, speaking, reading and writing. "The best practice in any situation will depend on the type of student, the words that are targeted, the school system and curriculum, and many others factor" (Schmitt, 2000: 142). And then Depdiknas (2004: 5) also adds the curriculum in Indonesia for example, said that students in first grade of junior high school have to have 500 vocabularies. So, the teachers have to encourage students to master 500 vocabularies in first grade of junior high school. But in fact, most of the students in Indonesia are having problems in lackness of vocabularies. Because of that, the students fell difficult to follow the English classroom activities. Likewise, Nation $(1990,2)$ said "Learners feel that many of their difficulties on both receptive and productive language use result from an inadequate vocabulary."

Based on the fact above, it is necessary and important for anyone who concerns in teaching English to find out the effective technique to make learning vocabulary easier and more pleasant for the students. So, they will enjoy following English class. In the learning vocabulary process, students usually have problems in absorbing the new vocabulary and their meaning. Michael J. Wallace $(1989,21)$ argued "Another teaching problem arises with words which are in the same rough area of meaning or semantic field."

To solve this problem, the writer gives an alternative technique for the teachers to enrich students' vocabulary that has connection with the area of semantic field. Why? Channel in Hedge $(2000,122)$ argued that "Semantic links play an important role in production. This suggests the use of semantic field based on presentation method..." So, the writer uses one of parts of semantic field to teach vocabulary by using hyponymy. It likes synonymy (a word similar in meaning) and antonym (a word opposite in meaning) using words relation to explain the meaning of the target word. CelceMurcia $(1991,301)$ said "A common way for teacher to elucidate the meaning of a target word is to relate it to another word that the students already know." Hyponymy is one way 
to make a hierarchy link by giving a word as a superordinate or general and some words as subordinate or specific, such as, "flower" as a superordinate and "rose", "jasmine", "orchid", etc. as the subordinate. It is hoped to help the teachers to explain vocabulary items easier by giving examples in the relation of a word with the other words. Harmer $(2001,17)$ adds that what a word means is often defined by its relationship to other words." Then, the students will have description about the vocabulary items which are explained by their teacher.

Finally, based on the background above, the writer would like to carry out the research under title "An Experimental Study of Teaching Vocabulary by Using Huponymy Games on the Seventh Grader of MTs Syech Ibrahim Payakumbuh".

\section{METHOD}

To collect data the writer uses field research by quasi experimental method. The population is all of the seventh grader at Seventh Grader of MTs Syech Ibrahim Payakumbuh. But, the writer just takes one class as the sample. The objects of the study is the sevetnth grade of $7_{c}$ class. She held the field research by taking the students' scores of the vocabulary tests (pre-test and post-test).

The techniques of data collection used in this research are:

\section{a. Teaching}

The writer did the teaching learning process six times, three times in control class and three times in experimental class before giving the post test to the students.

\section{b. Test}

The writer makes the instrument of this research that consisting of 25 questions vocabulary test. It is divided into three forms; the first part is multiple choices, the second part is structured essay and third part is unstructured essay.
They are divided into three categories: easy $(30 \%)$, middle $(60 \%)$, and difficult (10 $\%$ ).Multiple choices consists of 15 items from number 1 to number 15 . The score per items is 1. It means if students can choose the answer of 1 item correctly, they will get 1 score and if they can choose the answer of 15 items correctly, they will get 15 scores.

Matching test consists of 10 items from number 16 to number 20. It's score per item is 4. It means if students can choose the answer of 1 item correctly, they will get 4 score and if they can choose the answer of 5 items correctly, they will get 20 scores. Fill in the blank test consists of 5 items from number 20 to number 25. It's score per item is 3 . It means if students can choose the answer of 1 item correctly, they will get 3 score and if they can choose the answer of 5 items correctly, they will get 15 scores. If the students answer all item correctly, they will get scores 50. To get score 100, the score cross 2 . So, $50 \times 2=100$. From the description of each test from above, we can see that the high score of this test is 100 scores.

The instrument is vocabulary test by considering its validity and reliability before being used to collect data.

\section{Validity}

According to Anderson in Arikunto $(2003,65)$ said a test is valid if it measures what it purpose to measure. 1 In testing of items validity is used product moment formula from Pearson as follow:

$$
\begin{aligned}
r x y= & \frac{N \Sigma X Y-\left(\sum X\right)(\Sigma Y)}{\sqrt{\left[N \Sigma X^{2}-(\Sigma X)^{2}\right\}}\left[N \Sigma Y^{2}-(\Sigma Y)^{2}\right]} \\
& \text { rxy }=\text { Coefficient of correlation between } \\
& \mathrm{X} \text { Variable and Y Variable } \\
\mathrm{X} & =\text { Sum of score in X distribution } \\
\mathrm{Y} & =\text { Sum of score in Y distribution } \\
\mathrm{X}^{2} & =\text { Sum of X quadrate } \\
\mathrm{Y}^{2} & =\text { Sum of Y quadrate } \\
\mathrm{N} & =\text { Sum of sample }
\end{aligned}
$$

From the calculation about this test, the valid number that are $2,4,6,7,8,10,13,16$, 
$17,18,19,20,21,22,23,24,25$. It means from 25 question that was given, there 16 numbers which are valid. And 9 questions were not valid.

\section{Reliability}

According to Vockell and Asher (1995, 88) "Reliability addresses the question of whether the results of measuring processes are consistent on occasions when they should be consistent" The formula to be used to find out reliability by K-R. 20 (Kuder-Richardson 20) formula as follow:

$$
\begin{aligned}
& r 11=\left[\frac{n}{n-1}\right]\left[\frac{S^{2}-\sum p \cdot q}{S^{2}}\right] \text { dengan } S^{2}=\frac{\sum X^{2}-\left[\frac{\sum x}{n}\right]}{n} \\
& \text { r11 = Coefficient of reliability all of } \\
& \text { items test } \\
& \mathrm{S}^{2}=\text { Variance of items test } \\
& \mathrm{N}=\text { Sum of items test } \\
& \mathrm{P}=\text { Propose of student which the }
\end{aligned}
$$

With interpretation coefficient of reliability as follow:

$$
\begin{aligned}
& \text { DP : } 0.00-0.20=\text { Poor } \\
& \text { DP : } 0.21-0.40=\text { Satisfactory } \\
& \text { DP : } 0.41-0.70=\text { Good } \\
& \text { DP : } 0.71-1.00=\text { Excellent } \\
& \text { DP : Negative }=\text { All of poor }
\end{aligned}
$$

From the calculation of pre-test, the reliability score that the writer get is $\mathrm{r} 11=0.83$. The conclusion is that test reliable and include in category excellent.

\section{Discriminating Power}

According to Arikunto (2003, 211) "discriminating power adalah kemampuan sesuatu soal untuk membedakan antara siswa yang pandai (berkemampuan pandai) dengan siswa yang bodoh (berkemampuan rendah)"(Discriminating power is the capacity test to discriminate between clever student and below student).
The formula used to find out discriminating power as follow:

$$
D=\frac{B A}{J A}-\frac{B B}{J B}=P A-P B
$$

Explanation:

$$
\begin{aligned}
& \text { JA }=\text { Total of upper group } \\
& \text { (Banyaknya peserta kelompok atas) } \\
& \text { JB = Total of lower group } \\
& \text { (Banyaknya peserta kelompok bawah) } \\
& \begin{array}{l}
\text { BA = Total of upper student who } \\
\text { answer the test correctly } \\
\text { BB Total of lower student who } \\
\text { answer the test correctly PA = } \\
\text { Propose of upper student who } \\
\text { answer the test correctly } \\
\text { PB Propose of lower student who } \\
\text { answer the test correctly }
\end{array}
\end{aligned}
$$

(DP):

Classification of discriminating power

$$
\begin{aligned}
& \text { D : } 0.00-0.20=\text { Poor } \\
& \text { D : } 0.21-0.40=\text { Satisfactory } \\
& \text { D : } 0.41-0.70=\text { Good } \\
& \text { D : } 0.71-1.00=\text { Excellent } \\
& \text { D : Negative }=\text { All of poor }
\end{aligned}
$$

\section{Index of Difficulty}

According to Arikunto (2003, 208) "Bilangan yang menunjukkan sukar dan mudanya sesuatu soal disebut indeks kesukaran"(Difficulty index is the number which indicate difficult and easy of a test). The formula to be used to find out difficulty index as follow:

$$
P=\frac{B}{J S}
$$

\section{Explanation:}

$\mathrm{P}=$ Difficulty index

B = Sum of student who answer the test correctly

JS $\quad=$ Sum of all students

Classification of difficulty index: 


$$
\begin{aligned}
& 0.00-0.15=\text { Very difficult } \\
& 0.15-0.30=\text { Difficult } \\
& 0.31-0.70=\text { Average } \\
& 0.71-0.85=\text { Easy } \\
& 0.86-1.00=\text { Very easy }
\end{aligned}
$$

The writer used a quantitative data which is related to numerals and it is analyzed by statistics. She used "t-test" formula to calculate the data by comparing students' pretest and post-test. After collecting the data she needed in research, the data processed and analyzed through the following steps (Sudjono, 2000: 300):

a. Investigating students' vocabulary test, giving score, and describing score in table.

b. Determining mean of variable $\mathrm{x}$ with formula:

$$
M=\frac{\sum x}{N}
$$

c. Determining mean of variable y with formula:

$$
M y=\frac{\sum y}{N}
$$

d. Determining deviation standard of variable $\mathrm{x}$ and y with formula:

$$
S D D=\frac{\sum D^{2}}{n}-\frac{\left(\sum D\right)^{2}}{(N)}
$$

e. Determining standard error of mean of difference with formula:

$$
S E_{m D}=\frac{S D_{D}}{\sqrt{N-1}}
$$

f. Determining mean of difference

$$
M_{D}=\frac{\sum D}{N}
$$

g. Determining test of hypothesis (to)

$t_{0}=\frac{\sum M_{D}}{S E_{m D}}$

h. Determining degrees of freedom $(d f)$

$$
\begin{array}{cl}
\text { df }=N-1 & \\
\mathrm{M} & =\text { the average of score } \\
\mathrm{X} & =\text { the score of pre-test } \\
\mathrm{Y} & =\text { the score of poet-test } \\
\mathrm{N} & =\text { number of cases }
\end{array}
$$

\begin{tabular}{|c|c|}
\hline Students & Pre-test \\
\hline 1 & 45 \\
\hline 2 & 63 \\
\hline 3 & 65 \\
\hline 4 & 55 \\
\hline 5 & 71 \\
\hline 6 & 53 \\
\hline 7 & 56 \\
\hline 8 & 72 \\
\hline 9 & 55 \\
\hline 10 & 54 \\
\hline 11 & 46 \\
\hline 12 & 62 \\
\hline 13 & 71 \\
\hline 14 & 56 \\
\hline 15 & 54 \\
\hline 16 & 56 \\
\hline 17 & 71 \\
\hline 18 & 65 \\
\hline 19 & 59 \\
\hline 20 & 78 \\
\hline 21 & 62 \\
\hline 22 & 71 \\
\hline 23 & 62 \\
\hline 24 & 45 \\
\hline 25 & 55 \\
\hline 26 & 45 \\
\hline 27 & 64 \\
\hline 28 & 63 \\
\hline 29 & 66 \\
\hline
\end{tabular}

\section{RESEARCH FINDINGS}

\section{Data Description}

To know the the results of the students pre-test and post-test, the writer makes the table of the students, score such as follows. The test results of the experimental class are tabulated and calculated in the following table:

\section{Table 1}

The Result of Students' Pre-Test 


\begin{tabular}{c|c}
\hline 30 & 65 \\
\hline 31 & 62 \\
\hline 32 & 56 \\
\hline 33 & 71 \\
\hline 34 & 53 \\
\hline 35 & 67 \\
\hline 36 & 59 \\
\hline 37 & 58 \\
\hline 38 & 61 \\
\hline 39 & 58 \\
\hline 40 & 71 \\
\hline Total & 2421
\end{tabular}

Based on the table above, the writer calculated the result of variable $\mathrm{x}(\Sigma \mathrm{x})$ is 2212 , and seeking the mean score of variable $y$, the higher score, and the lower score of the students' pre- test with formula:

- Error! Reference source not found.

- $\quad$ The higher score $=71$

- The lower score $=45$

Table 1

The Result of The Students' Post-Test

\begin{tabular}{c|c}
\hline Students & Post-test \\
\hline 1 & 75 \\
\hline 2 & 76 \\
\hline 3 & 64 \\
\hline 4 & 61 \\
\hline 5 & 70 \\
\hline 6 & 65 \\
\hline 7 & 67 \\
\hline 8 & 87 \\
\hline 9 & 75 \\
\hline 10 & 71 \\
\hline 11 & 68 \\
\hline 12 & 69 \\
\hline 13 & 72 \\
\hline 14 & 62 \\
\hline 15 & 71 \\
\hline 16 & 69 \\
\hline 17 & 80 \\
\hline 18 & 65 \\
\hline 19 & 73 \\
\hline 20 & 79 \\
\hline 21 & 71 \\
\hline &
\end{tabular}

\begin{tabular}{c|c}
\hline 22 & 73 \\
\hline 23 & 70 \\
\hline 24 & 61 \\
\hline 25 & 61 \\
\hline 26 & 63 \\
\hline 27 & 72 \\
\hline 28 & 75 \\
\hline 29 & 69 \\
\hline 30 & 65 \\
\hline 31 & 75 \\
\hline 32 & 67 \\
\hline 33 & 76 \\
\hline 34 & 61 \\
\hline 35 & 64 \\
\hline 36 & 60 \\
\hline 37 & 73 \\
\hline 38 & 72 \\
\hline 39 & 62 \\
\hline 40 & 78 \\
\hline Total & 2787
\end{tabular}

Based on the data collected in post-test, the writer calculated the result of variable $y$ $(\Sigma y)$ is 2212. Then she calculated the mean score of variable $\mathrm{y}$, and seeking the higher score, and the lower score of the students' pretest with formula:

- Error! Reference source not found.

- $\quad$ The higher score $=87$

- The lower score $=61$

\section{The Comparison of Students' Pre-test and Post-test}

After getting the data, the writer analyzed it by using statistic calculation of test formula.

Table 3

The Result of The Students' English Pre-Test And Post-Test

\begin{tabular}{c|c|c|c|c}
\hline Stdts & $\begin{array}{c}\text { Pre- } \\
\text { test }\end{array}$ & $\begin{array}{c}\text { Post- } \\
\text { test }\end{array}$ & $\mathbf{D}=(\mathbf{x}-\mathbf{y})$ & $\mathbf{D}^{\mathbf{2}}=(\mathbf{x}-\mathbf{y})$ \\
\hline 1 & 45 & 75 & -30 & 900 \\
\hline 2 & 63 & 76 & -13 & 169 \\
\hline 3 & 65 & 64 & +1 & 1 \\
\hline 4 & 55 & 61 & -6 & 36 \\
\hline
\end{tabular}




\begin{tabular}{|c|c|c|c|c|}
\hline 5 & 71 & 70 & +1 & 1 \\
\hline 6 & 53 & 65 & -8 & 64 \\
\hline 7 & 56 & 67 & -11 & 121 \\
\hline 8 & 72 & 87 & -15 & 125 \\
\hline 9 & 55 & 75 & -10 & 100 \\
\hline 10 & 54 & 71 & -16 & 196 \\
\hline 11 & 46 & 68 & -22 & 484 \\
\hline 12 & 62 & 69 & -7 & 49 \\
\hline 13 & 71 & 72 & -1 & 1 \\
\hline 14 & 56 & 62 & -6 & 36 \\
\hline 15 & 54 & 71 & -17 & 289 \\
\hline 16 & 56 & 69 & -13 & 169 \\
\hline 17 & 71 & 80 & -9 & 81 \\
\hline 18 & 65 & 65 & 0 & 0 \\
\hline 19 & 59 & 73 & -14 & 196 \\
\hline 20 & 78 & 79 & -1 & 1 \\
\hline 21 & 62 & 71 & -9 & 81 \\
\hline 22 & 71 & 73 & -2 & 4 \\
\hline 23 & 62 & 70 & -8 & 64 \\
\hline 24 & 45 & 61 & -16 & 196 \\
\hline 25 & 55 & 61 & -8 & 64 \\
\hline 26 & 45 & 63 & -16 & 196 \\
\hline 27 & 64 & 72 & -8 & 64 \\
\hline 28 & 63 & 75 & -12 & 144 \\
\hline 29 & 66 & 69 & -3 & 9 \\
\hline 30 & 65 & 65 & 0 & 0 \\
\hline 31 & 62 & 75 & -13 & 169 \\
\hline 32 & 56 & 67 & -21 & 441 \\
\hline 33 & 71 & 76 & -5 & 25 \\
\hline 34 & 53 & 61 & -8 & 64 \\
\hline 35 & 67 & 64 & +3 & 9 \\
\hline 36 & 59 & 60 & -1 & 1 \\
\hline 37 & 58 & 73 & -15 & 125 \\
\hline 38 & 61 & 72 & -11 & 121 \\
\hline 39 & 58 & 62 & -4 & 16 \\
\hline 40 & 71 & 78 & -7 & 49 \\
\hline Total & 2421 & 2787 & -361 & 4861 \\
\hline
\end{tabular}

According to the data in the table above, the writer calculated the result of the students' pre-test (variable $\mathrm{x}$ ) and post-test (variable $\mathrm{y}$ ). The first steps was seeking the difference between variable $\mathrm{x}$ and $\mathrm{y}$ and we got it by using formula $\mathrm{x}-\mathrm{y}=\mathrm{D}, \Sigma \mathrm{D}=-721$ and $\Sigma \mathrm{D} 2=15405$. After that, we seek the standard of difference between two variables ( $\mathrm{x}$ and $\mathrm{y}$ ) using formula as follow:

$$
\begin{aligned}
& S D_{D}=\sqrt{\frac{\sum D^{2}}{N}-\frac{\left(\sum D\right)^{2}}{N}} \\
& S D_{D}=\sqrt{\frac{4861}{40}-\frac{(-361)^{2}}{(40)}}
\end{aligned}
$$

\section{Error! Reference source not found. $=6.33$}

After finding the result of SDD, we can seek SEMD (Strandard Error of the Mean difference) using formula:

$$
\begin{aligned}
& S E M_{D}=\frac{S D_{D}}{\sqrt{N-1}} \\
& S E M_{D}=\frac{6.33}{\sqrt{40-1}} \\
& S E M_{D}=\frac{6.33}{\sqrt{39}} \\
& S E M_{D}=\frac{6.33}{6.24}=1.014
\end{aligned}
$$

After the result of SEMD was found, we seek MD (Mean of Difference) using formula as follows:

$$
\begin{aligned}
& M_{\bar{D}}=\frac{\sum D}{N} \\
& M_{D}=\frac{361}{40}=9.025
\end{aligned}
$$

Notes:

$\mathrm{N}=$ Number of cases

$\mathrm{x}=$ the score of pre-test

$y=$ the score of post- test

$\mathrm{D}=$ difference

$\Sigma \mathrm{x}=$ the total score of $\mathrm{x}$

$\Sigma y=$ the total score of $y$

$\Sigma \mathrm{D}=$ the total of difference

$\Sigma$ D2 $=$ the total of quadrate difference

Finally, we seek to (Test of Hypothesis), using formula as follow:

$$
\begin{aligned}
& t_{o}=\frac{M_{D}}{S E M_{n}} \\
& t_{o}-\frac{9.025}{1.014}-8.9 \\
& d f=\left(N_{1}+N_{2}-2\right)=40+40-2=78
\end{aligned}
$$


There is no degree of freedom for 78 , so the writer uses the close df from 80 at significance $5 \%=2,64$

\section{Hypothesis Testing}

To prove the hypothesis, the data obtained from the experimental class and the controlled classes are calculated by using the $\mathrm{t}$ test formula with assumption as follows:

If to $>\mathrm{tt}$ : There is a significant diffrerence and the alternative hypothesis $(\mathrm{Ha})$ is accepted and null hypothesis (Ho) is rejected.

If to $<\mathrm{tt}:$ There is a significant diffrerence and the alternative hypothesis $(\mathrm{Ha})$ is rejected and null hypothesis (Ho) is accepted.

From the result of statistic calculation, it is obtained the value of $t_{o}$ is 8,9 and degrees of freedom (df) is 78 . The result of significant $5 \%$ is 2,64 . The comparison between $t$-score with $t-$ table, $\mathrm{t}$-score $=2,64<8,9$. It means that hypothesis of the research is accepted, or there is significant difference between the results of teaching vocabulary through hyponymy games for the Seventh Grader of MTs Syech Ibrahim Payakumbuh.

\section{DISCUSSION}

The purpose of this study is to examine the effectiveness of Hyponymy Games on teaching Vocabulary for the seventh grader of MTs Syech Ibrahim Payakumbuh. In the light of the finding of this study, it can be stated that the main result is that Hyponymy games are highly effective in developing students' level of vocabulary in the experimental group compared to control group's results. The researcher attributes this to the following results.

First, the junior high school students lose attention quickly and easily, so this game can attract the student's attention. And the researcher notices that when she applied this games, the students concentrated better and through the vocabulary easily. Second, the researcher follows logic steps when presenting the lesson. She starts by warming up to activate the students, than begin to make a brainstorm of previous information related to the topic given. After that, she presents the new vocabulary through Hyponymy games and then practices the new vocabulary in real situation. These steps make lesson clear, interesting, and useful for the young learners, so that they do not lose attention and concentration.

Moreover, it shows that language learning can be fun. It has been stated before that students should learn new word all the time which simply presented as list of vocabulary to be learnt. Beside, as a foreign language where English is not use in everyday life, recalling vocabulary can be done through games which present as plays, have quite demanding on serious purpose. While the students are playing games, they are strongly motivate toward correctness by their earlier education each student will do the best to produce the language.

\section{CONCLUSION}

According to the research of the analysis of the research, it shows that the value of "to" ( $t$ test) is bigger than the value of " $\mathrm{tt}$ " ( $\mathrm{t}$ table). So, the null hypothesis (Ho) is rejected and the alternative hypothesis $(\mathrm{Ha})$ is accepted. Or it can be said that there significant influence of using hyponymy in teaching vocabulary.

It can be concluded that teaching vocabulary using hyponymy games is adequate success. It can be seen from the calculation above and from the table of the students' vocabulary scores by using hyponymy games is increase from pre test to post test. It means there is significant influence of using hyponymy in teaching vocabulary.

\section{REFERENCES}

Aebersold, A.J. \& Mary, L. F. (1997). From Reader to English Teacher, Cambridge : Cambrigde University Press. 
Anas, S. (2000). Pengantar Statistik Pendidikaan, Jakarta: PT. Raja Grafindo Persada.

Arikunto, S. (2003). Dasar-Dasar Evaluasi Pendidikan, Jakarta: Bumi Aksara.

Martyn, B. (1999). The Development of Language, London: Psychology Press.

Cameron, L. (2001). Teaching Language to Young Learners, Cambridge: Cambridge University Press.

Carter, R. (2000). Vocabulary- Applied Linguistic Perspective-Second Edition, New York: Routledge.

Celce Murcia, M. (1991). Teaching English as a Second Language or Foreign Language, Second Edition, Massachusetts: Heinle Publisher.

Depdiknas. (2003). Kurikulum 2004 Standar Kompetensi SMP dan MTS, Jakarta: Departemen Pendidikan Nasional.

Edward, L. V. \& Asher, J.W. (1995). Educational Research. New Jersey: Prentice Hall.

Harmer, J. (1983). The Practice of English Language Teaching, London : Longman Group.

Hedge, T. (2000). Teaching and Learning in the Classroom, Oxford Oxford University Press.

Larsen, D. \& Freeman. (1986). Techniques \& Principles in Language Teaching, Oxford: Oxford University Press.

Nation, S P I. (1990). Teaching and Learning Vocabulary, Massachusets: Heinle \& Heinle Publisers.

(2001). Learning Vocabulary in Another Language, Cambridge: Cambridge University Press.
Nunan, David. (1991). Language Teaching Methodology, New Jersey: Prentice Hall International.

Philips, A. \& Gonzalez, M. (2004). Philip, B.G. (1999). Webster's Third New International Dictionary, Massachusetts: Massahusetts. G and C Meriam Company.

Modern Language- Learning and Teaching in an Intercultural Field, London: Sage Publications.

Read, J. (2000). Assessing Vocabulary, Cambrigde: Cambridge University Press.

Schimtt, N. (2000). Vocabulary in Language Teaching, Cambridge: Cambridge University Press.

Schmitt, N \& Mc Carthey, M. (1997). Vocabulary in Language Teaching, New York: Cambrigde University Press.

Thorbury, S. (2002). How to Teach Vocabulary, London: Longman.

Ur, P. (1996). A Course in Language Teaching: Practice and Theory, New York: Cambridge University Press.

Wallace, J. M. (1989). Teaching Vocabulary, London: Biddles Ltd, Guilford and King's Lynn.

Wright, A., Betteridge, D \& Buckby, M. (2006). Games for Language Learning, Cambridge: Cambridge University Press.

Yule, G. (2006). The Study of Language -Third Edition, New York: Cambrigde University Press.

Zaenuri, M A. (2001). English Vocabulary I, Revised Edition, Jakarta.Thielsen, V. A., \& Leahy, M. J. (2001). 